\title{
Evolution of particle composition in CLOUD nucleation experiments
}

H. Keskinen ${ }^{1}$, A. Virtanen ${ }^{1}$, J. Joutsensaari ${ }^{1}$, G. Tsagkogeorgas ${ }^{2}$, J. Duplissy ${ }^{3}$, S. Schobesberger ${ }^{3}$, M. Gysel $^{4}$, F. Riccobono ${ }^{4}$, J. G. Slowik ${ }^{4}$, F. Bianchi ${ }^{4}$, T. Yli-Juuti ${ }^{3}$, K. Lehtipalo ${ }^{3}$, L. Rondo ${ }^{5}$, M. Breitenlechner ${ }^{6}$, A. Kupc ${ }^{7}$, J. Almeida ${ }^{5}$, A. Amorim ${ }^{8}$, E. M. Dunne ${ }^{9,10}$, A. J. Downard ${ }^{11}$, S. Ehrhart ${ }^{5}$, A. Franchin ${ }^{3}$, M.K. Kajos ${ }^{3}$, J. Kirkby ${ }^{12}$, A. Kürten ${ }^{6}$, T. Nieminen ${ }^{3}$, V. Makhmutov ${ }^{13}$, S. Mathot $^{12}$, P. Miettinen ${ }^{1}$, A. Onnela ${ }^{12}$, T. Petäjää , A. Praplan ${ }^{4}$, F. D. Santos ${ }^{8}$, S. Schallhart ${ }^{3}$, M. Sipilä ${ }^{3,14}$, Y. Stozhkov ${ }^{13}$, A. Tomé ${ }^{15}$, P. Vaattovaara $^{1}$, D. Wimmer ${ }^{5}$, A. Prevot ${ }^{4}$, J. Dommen $^{4}$, N. M. Donahue ${ }^{16}$, R.C. Flagan ${ }^{11}$, E. Weingartner ${ }^{4}$, Y.Viisanen ${ }^{17}$, I. Riipinen ${ }^{18}$, A. Hansel ${ }^{6,19}$, J. Curtius ${ }^{5}$, M. Kulmala ${ }^{3}$, D. R. Worsnop ${ }^{1,3,20}$, U. Baltensperger ${ }^{4}$, H. Wex $^{2}$, F. Stratmann ${ }^{2}$, and A. Laaksonen ${ }^{1,17}$

${ }^{1}$ Dept. of Applied Physics, University of Eastern Finland, Kuopio, Finland

${ }^{2}$ Dept. of Physics, Leibniz Institute for Tropospheric Research, Leibniz, Germany

${ }^{3}$ Dept. of Physics, University of Helsinki, Helsinki, Finland

${ }^{4}$ Laboratory of Atmospheric Chemistry, Paul Scherrer Institute, Villigen, Switzerland

${ }^{5}$ Institute for Atmospheric and Environmental Sciences, Johann Wolfgang Goethe University Frankfurt, Frankfurt, Germany

${ }^{6}$ Institute for Ion and Applied Physics, University of Innsbruck, Innsbruck, Austria

${ }^{7}$ Faculty of Physics, University of Vienna, Vienna, Austria

${ }^{8}$ University of Lisbon, Lisbon, Portugal

${ }^{9}$ School of Earth and Environment, University of Leeds, Leeds, UK

${ }^{10}$ Finnish Meteorological Institute, Kuopio, Finland

${ }^{11}$ Division of Chemistry and Chemical Engineering, California Institute of Technology, California, USA

${ }^{12}$ Centre européen pour la recherche nucléaire (CERN), Geneva, Switzerland

${ }^{13}$ Solar and Cosmic Ray Research Laboratory, Lebedev Physical Institute, Moscow, Russia

${ }^{14}$ Institute of Physics, University of Helsinki, Helsinki, Finland

${ }^{15}$ University of Beira Interior, Beira, Portugal

${ }^{16}$ Carnegie Mellon University, Center of Atmospheric Particle Studies, Pittsburgh, USA

${ }^{17}$ Finnish Meteorological Institute, Helsinki, Finland

${ }^{18}$ University of Stockholm, Stockholm, Sweden

${ }^{19}$ Ionicon Analytik GmbH, Innbruck, Austria

${ }^{20}$ Aerodyne Research, Billerica, Massachusetts, USA

Correspondence to: H. Keskinen (helmi.keskinen@uef.fi)

Received: 22 November 2012 - Published in Atmos. Chem. Phys. Discuss.: 4 December 2012 Revised: 6 May 2013 - Accepted: 7 May 2013 - Published: 6 June 2013

\begin{abstract}
Sulphuric acid, ammonia, amines, and oxidised organics play a crucial role in nanoparticle formation in the atmosphere. In this study, we investigate the composition of nucleated nanoparticles formed from these compounds in the CLOUD (Cosmics Leaving Outdoor Droplets) chamber experiments at CERN (Centre européen pour la recherche nucléaire). The investigation was carried out via analysis of the particle hygroscopicity, ethanol affinity, oxidation state,
\end{abstract}

and ion composition. Hygroscopicity was studied by a hygroscopic tandem differential mobility analyser and a cloud condensation nuclei counter, ethanol affinity by an organic differential mobility analyser and particle oxidation level by a high-resolution time-of-flight aerosol mass spectrometer. The ion composition was studied by an atmospheric pressure interface time-of-flight mass spectrometer. The volume fraction of the organics in the particles during their 
growth from sizes of a few nanometers to tens of nanometers was derived from measured hygroscopicity assuming the Zdanovskii-Stokes-Robinson relationship, and compared to values gained from the spectrometers. The ZSR-relationship was also applied to obtain the measured ethanol affinities during the particle growth, which were used to derive the volume fractions of sulphuric acid and the other inorganics (e.g. ammonium salts). In the presence of sulphuric acid and ammonia, particles with a mobility diameter of $150 \mathrm{~nm}$ were chemically neutralised to ammonium sulphate. In the presence of oxidation products of pinanediol, the organic volume fraction of freshly nucleated particles increased from 0.4 to $\sim 0.9$, with an increase in diameter from 2 to $63 \mathrm{~nm}$. Conversely, the sulphuric acid volume fraction decreased from 0.6 to 0.1 when the particle diameter increased from 2 to $50 \mathrm{~nm}$. The results provide information on the composition of nucleated aerosol particles during their growth in the presence of various combinations of sulphuric acid, ammonia, dimethylamine and organic oxidation products.

\section{Introduction}

Aerosol hygroscopicity, i.e. the ability of aerosol particles to take up water, is important when estimating the effect of atmospheric aerosol particles on our climate. The aerosol direct effect on climate (scattering of sunlight back to space) depends on the size of the atmospheric particles, which in turn depends on the particle hygroscopicity and the surrounding relative humidity. Freshly nucleated nanoparticles in the atmosphere can grow into the size range where they are large enough to act as cloud condensation nuclei (Merikanto et al., 2009), and therefore can become important for cloud processes. It is therefore important to include information on nucleated aerosol composition and hygroscopicity in climate models to improve estimates of aerosol radiative forcing. Nanoparticle formation via nucleation in the presence of atmospheric vapours and their subsequent condensational growth have been reported to produce atmospheric aerosol in a variety of environments (e.g. Kulmala et al., 2004; Hamed et al., 2007). Numerous modelling studies suggest that these particles are likely to have a significant impact on climate (Carslaw et al., 2010). Particles are referred to as secondary organic aerosol (SOA) when oxidation products of volatile organic compounds (VOCs), emitted by biogenic and anthropogenic sources, participate in the formation and growth process of these newly formed atmospheric particles (Laaksonen et al., 2008; Kanakidou et al., 2005; Jimenez et al., 2009; Claeys et al., 2004; Hallquist et al., 2009).

SOA formation and properties are widely studied to clarify their role in global aerosol radiative forcing. State-ofthe-art chamber studies, such as those performed within the framework of the CLOUD (Cosmics Leaving Outdoor Droplets) project at CERN (Centre européen pour la recherche nucléaire), simulate these aerosol formation processes (Kirkby et al., 2011). There have been several recent studies concentrating on hygroscopic properties of SOA particles, both in the laboratory and the field, to clarify their climatic effects (e.g. VanReken, et al., 2005; Jurányi et al., 2009; King et al., 2009; Wex et al., 2009; Massoli et al., 2010; Meyer et al., 2009; Duplissy et al., 2011). Recently, Jimenez et al. (2009) and Massoli et al. (2010) summarised the effect of the oxidation state of SOA particles on their hygroscopic properties. They found that higher oxidation levels led to higher hygroscopicity of the particles.

As the chemical composition of the particles affects their hygroscopic properties (Pruppacher and Klett, 1997), it is possible to infer information on their composition from hygroscopic growth measurements if the hygroscopic growth factors of specific compounds are known (Raatikainen et al., 2010; Duplissy et al., 2011; Smith et al., 2012; Petäjä et al., 2005). The composition of freshly nucleated atmospheric particles in a eucalyptus forest has been studied by combining particle hygroscopic growth and volatility properties (Ristovski et al., 2010). Also, ethanol affinity (i.e. the particles' ability to uptake ethanol) can give complementary information on the particle composition in atmospheric studies, especially when the particles contain different compounds with equal hygroscopic growth (Joutsensaari et al., 2001; Vaattovaara et al., 2005). It is possible to gain information on the nucleated nanoparticles' size-dependent composition during their growth via the direct and indirect experimental methods presented above. This can provide information on the topical question of the organic contribution to particle growth during nucleation (Pierce et al., 2011; Donahue et al., 2011; Riipinen et al., 2012). In this study we concentrate on studying the hygroscopicity of inorganic and mixed inorganic/organic particles formed in the CERN CLOUD chamber. We use a hygroscopic tandem differential mobility analyser (H-TDMA) and a cloud condensation nuclei counter (CCNC). In addition, we combine the data from an atmospheric pressure interface time-of-flight mass spectrometer (APi-TOF), H-TDMA, organic tandem differential analyser (O-TDMA) and an aerosol mass spectrometer (AMS) to provide further information on the particle composition in the size range from 2 to $60 \mathrm{~nm}$. Special attention is given to the organic volume fraction of the particles during their growth. The sulphuric acid volume fraction in the particles is also derived from experimental results (H/O-TDMA) in the size range from 15 to $50 \mathrm{~nm}$ and compared with the extended aerosol inorganic model (E-AIM).

\section{Experimental}

\subsection{Chamber and sampling}

The particle formation experiments were carried out in the CLOUD chamber located at CERN. A detailed description 
Table 1. Summary of the experiments analysed in this study. The experiments were performed in the presence of sulphuric acid $\left(\mathrm{H}_{2} \mathrm{SO}_{4}\right)$ and ammonia $\left(\mathrm{NH}_{3}\right)$ (Exp. A), and pinanediol (PD) (Exp. B-C). $\mathrm{NH}_{3}, \mathrm{H}_{2} \mathrm{SO}_{4}$, DMA and PD refer to gas-phase concentrations of ammonia, sulphuric acid, dimethylamine and pinanediol, respectively; "type" indicates run conditions (ch: pion beam in use, gcr: natural galactic cosmic rays only); "UV" indicates UV-lamp aperture opening in \% or UVS; $d_{\text {dry }}$ is TDMA dry particle diameter; $d_{\mathrm{ccn}}$ is CCNC selected dry particle diameter. The ozone $\left(\mathrm{O}_{3}\right)$ concentration was $\sim 500 \mathrm{ppb}$ for Exp. A and below $100 \mathrm{ppb}$ for Runs B-C.

\begin{tabular}{lllllll}
\hline Run & $\mathrm{NH}_{3}$ & $\mathrm{H}_{2} \mathrm{SO}_{4}$ & Dimethylamine & $\mathrm{PD}$ & Type & UV \\
\hline & (pptv) & $\left(10^{6}\right.$ molecules $\left.\mathrm{cm}^{-3}\right)$ & (pptv) & $\left(10^{3} \mathrm{pptv}\right)$ & & \\
$\mathrm{A}$ & $\sim 10-20^{*}$ & 330 & none & none & neutral & UVS \\
$\mathrm{B}$ & 10 & $1 \pm 0.2$ & 1 & $10 \pm 2$ & $\mathrm{ch}$ & $\mathrm{UVS}$ \\
$\mathrm{C}$ & 10 & $4.5 \pm 0.5$ & 2 & $26 \pm 4$ & $\mathrm{gcr}$ & $100 \%$ \\
\hline
\end{tabular}

* $\mathrm{NH}_{3}$ background estimation based on Praplan et al. (2012).

of the CLOUD experiment can be found elsewhere (Kirkby et al., 2011). Briefly, the chamber consists of a cylindrical stainless steel tank with a volume of $26.1 \mathrm{~m}^{3}$ (Kirkby et al., 2011), an ultraviolet (UV) system (Kupc et al., 2011), and a gas mixing system (Voigtlander et al., 2012). Inside the chamber, atmospheric conditions were recreated and exposed to a CERN pion beam line, which closely replicates natural cosmic rays (Duplissy et al., 2010).

In order to provide precursor vapours for particle formation, ozone $\left(\mathrm{O}_{3}\right)$, sulphur dioxide $\left(\mathrm{SO}_{2}\right)$, ammonia $\left(\mathrm{NH}_{3}\right)$, dimethylamine $\left(\left(\mathrm{CH}_{3}\right)_{2} \mathrm{NH}\right)$ and pinanediol $\left(\mathrm{PD} ; \mathrm{C}_{10} \mathrm{H}_{18} \mathrm{O}_{2}\right)$ were introduced into the chamber. Two UV-light systems were used during measurements: the first involved a fibreoptic UV-illumination system (Kupc et al., 2011), while the second was a factor-100 higher intensity UV-source installed in a quartz tube inserted into the chamber (UVS). The UV systems were mainly used for in situ production of OH radicals necessary for the formation of both sulphuric acid (SA) vapour and PD oxidation species. During these experiments the chamber was kept at a constant temperature of $278 \mathrm{~K}$ (with $\pm 0.01 \mathrm{~K}$ typical stability) and a relative humidity (RH) of $38 \%( \pm 1 \%)$.

The evolution of the particle mobility size distribution during nucleation and the growth rates (GRs) of the particles were determined with a scanning mobility particle sizer (SMPS, with a custom-built differential mobility analyser (DMA) with similar specifications to TSI model 3085 nanoDMA). GRs were also used to obtain the concentration of the sulphuric acid in nucleated nanoparticles; the details of the analysis can be found elsewhere (Nieminen et al., 2010). GRs were also used to obtain the volume fraction of sulphuric acid in nucleated nanoparticles. In the GR analysis, we used the SA gas phase concentration measured by the CIMS. The theoretical maximum GR from condensation of gas phase SA onto the particles was calculated according to the method of Nieminen et al. (2010). The ratio of GR from SA condensation to the observed particle GR calculated based on SMPS data gives the fraction of particle growth explained by sulphuric acid. To study the chemical composition of particles and their ability to act as cloud condensation nuclei (CCN), we used data from the H- and O-TDMA (custom-built, Joutsensaari et al., 2001), a CCNC (Droplet Measurement Technologies, Lance et al., 2006; Roberts and Nenes, 2005), and a HR-ToF-AMS. The measured size ranges were $15-150 \mathrm{~nm}$ for the $\mathrm{H}-$ and the O-TDMA, $43-125 \mathrm{~nm}$ for the CCNC and $>50 \mathrm{~nm}$ for the HR-ToF-AMS. To study the composition of ions up to $2 \mathrm{~nm}$ in mobility diameter, an APi-TOF was used. The chamber conditions for experimental runs analysed in this study are listed in Table 1. The sulphuric acid concentration was measured using a chemical ionisation mass spectrometer (CIMS; Kurtén et al., 2011). Pinanediol concentrations were derived from a proton transfer reaction-mass spectrometer (PTR-MS) (Hansel et al., 1995). The measurement of concentrations of $\mathrm{NH}_{3}$ and DMA are reported in Bianchi et al. (2012) and Praplan et al. (2012), respectively. The UV system is described in Kupc et al. (2011).

\subsection{H-TDMA, O-TDMA and CCNC}

The particles produced inside the chamber were fed to the H-TDMA, O-TDMA and CCNC through the same sampling line. The particles were initially passed through a silica-gel diffusion dryer and then charged using a bipolar diffusion charger (Kr-85, TSI). The flow of the charged particles was then distributed separately to the H/O-TDMAs and CCNC. The growth factors of nanoparticles in subsaturated water and ethanol vapour were measured using the H-TDMA and the O-TDMA, respectively (Joutsensaari et al., 2001). Both TDMAs employ two DMAs (Vienna-type medium) (Knutson and Whitby, 1975). In each instrument, the first DMA, designated as DMA1, was used to select the initial particle sizes of $15,30,50,75,80$, and $150 \mathrm{~nm}$ from the polydisperse aerosol sample flow. In the H-TDMA, downstream of the DMA1, the sample flow was humidified by a system consisting of GoreTex tubing for diffusional transfer of the water vapour into the flow. The residence time in the humidified section of H-TDMA system was $5 \mathrm{~s}$. After humidification of the sample flow, the particle size distribution was measured by the second DMA, designated DMA2, and a condensation particle counter (CPC; model 3786 and 3010, TSI Inc., USA). In the H-TDMA, DMA2 had a closed-loop sheath-air 
circulation system where the incoming sample flow humidifies the sheath air flow circulating in DMA2. In the OTDMA, the ethanol saturation ratio inside DMA2 was controlled by mixing ethanol-saturated (saturation ratio near 1) air with dry air, using mass flow controllers (open loop). Ethanol-saturated air was generated by streaming dry air through an ethanol evaporation chamber. In the H-TDMA, the RH and temperature inside DMA2 were determined in the sample flow using a capacitive sensor (Rotronic) and in the sheath flow using a dew-point meter (Dewmaster). The O-TDMA saturation ratio was monitored using a dew-point measurement (General Eastern) from the DMA2 excess flow. This entire set-up was placed in a temperature-controlled box (accuracy in the set-up $\pm 0.5^{\circ} \mathrm{C}$ ) to ensure an accurate $( \pm 1 \%)$ humidity measurement. The aerosol and sheath air RH were kept constant to within $1 \%$ of the set point. The mobility number size distributions were determined with a conventional stepping mode method using a standard DMA data inversion algorithm (Reischl, 1991). In the data processing, we fitted log-normal distributions to the size distributions measured by DMA2 and derived the geometric mean diameter $d_{\mathrm{RH}}$ or $d_{\mathrm{EH}}$ after water or ethanol humidification. From these measurements, assuming the measured particles to be spherical, we could define the hygroscopic (HGF) and ethanol growth factor (EGF) as the ratio of the humidified or ethanol vapour treated to the dry particle diameter:

$\mathrm{HGF}=\frac{d_{\mathrm{RH}}}{d_{\mathrm{dry}}}, \mathrm{EGF}=\frac{d_{\mathrm{EH}}}{d_{\mathrm{dry}}}$

where $d_{\text {dry }}$ is the measured geometric mean mobility diameter for dry particles (RH below $5 \%$ ) and $d_{\mathrm{RH}}$ and $d_{\mathrm{EH}}$ are the geometric mean mobility diameters after exposure to subsaturated concentrations of water or ethanol vapour, respectively.

The calibrations of the H- and O-TDMA during CLOUD experiments were performed simultaneously at regular time intervals using $\left(\mathrm{NH}_{4}\right)_{2} \mathrm{SO}_{4}$ nanoparticles produced by an atomiser. Growth factors for $\left(\mathrm{NH}_{4}\right)_{2} \mathrm{SO}_{4}$ particles were measured at defined relative vapour subsaturations $(90 \%$ and $80 \%)$ for different particle diameters $(15 \mathrm{~nm}, 30 \mathrm{~nm}, 50 \mathrm{~nm})$.

The hygroscopicities $(\kappa)$ and ethanol affinities $(\eta)$ from TDMA-measurements were calculated based on Petters and Kreidenweis (2007):

$$
\begin{gathered}
\kappa=\left(\mathrm{HGF}^{3}-1\right) \cdot\left[\frac{1}{S} \cdot \exp \left(\frac{4 \sigma_{\mathrm{w}} M_{\mathrm{w}}}{R T \rho_{\mathrm{w}} d_{\mathrm{dry}} \mathrm{HGF}}\right)-1\right] \\
\eta=\left(\mathrm{EGF}^{3}-1\right) \cdot\left[\frac{1}{S} \cdot \exp \left(\frac{4 \sigma_{\mathrm{e}} M_{\mathrm{e}}}{R T \rho_{\mathrm{e}} d_{\mathrm{dry}} \mathrm{EGF}}\right)-1\right]
\end{gathered}
$$

where $S$ is the saturation ratio, $\sigma_{\mathrm{w}} / \sigma_{\mathrm{e}}$ is the water/ethanol surface tension, $M_{\mathrm{w}} / M_{\mathrm{e}}$ is the molecular weight of the water/ethanol, $R$ is the ideal gas constant, $T$ is the temperature in Kelvin, $\rho_{\mathrm{w} / \mathrm{e}}$ is the density of the liquid water/ethanol and $d_{\text {dry }}$ is the dry diameter of particles selected by DMA1.
For the CCNC measurements, the size selection of the dried aerosol particles was done with another DMA (Viennatype, medium). Downstream of the DMA, the monodisperse particles were fed into a CPC (TSI 3010) and then into a continuous-flow thermal-gradient cloud condensation nuclei counter (CCNC). The CPC measured the total number concentration of condensation nuclei, while the CCNC measured the concentration of particles which activated to form a droplet at a constant water supersaturation. The supersaturation in the CCNC ranged from 0.3 to $1.4 \%$ and the dry particle size ranged from 43 to $125 \mathrm{~nm}$ in mobility diameter. From the resulting supersaturation and particle dry diameter pairs, particle hygroscopicity, i.e. kappa values for droplet activation, were determined according to Petters and Kreidenweis (2007):

$\kappa_{\mathrm{CCN}}=\left[\left(\frac{4\left(\frac{4 \sigma_{\mathrm{w}} M_{\mathrm{w}}}{R T \rho_{\mathrm{w}}}\right)^{3}}{27 d_{\mathrm{dry}}^{3} \ln ^{2} S_{\mathrm{c}}}\right)-1\right]$

where $S_{\mathrm{c}}$ is the critical supersaturation for each dry diameter $\left(d_{\text {dry }}\right)$.

The theoretical hygroscopic growth factors and hygroscopicities for sulphuric acid (SA), ammonium sulphate (AS) and ammonium bisulphate (AbS) were derived based on experiments (Joutsensaari et al., 2001, 2004; Hämeri et al., 2000; Vehkamäki et al., 2002) and model results reported elsewhere (Topping et al., 2005). The theoretical ethanol growth factors and affinities were derived based on methods and experiments reported by Joutsensaari et al. (2001) and Vaattovaara et al. (2005).

\subsection{APi-TOF and HR-ToF-AMS}

To determine the composition during the earliest steps of particle production in the chamber, ions in the mass/charge range up to 2000 Th were measured by an APi-TOF (Tofwerk AG \& Aerodyne Research, Inc.). The instrument is described in detail by Junninen et al. (2010). Up-to-date versions of tofTools, a software package based on MATLAB, were used to process and analyse the data, and to determine the elemental compositions of the dominant ion compounds based on their exact mass and isotopic distributions. We converted masses to mobility-equivalent diameters, as described in Ehn et al. (2011), assuming estimated densities corresponding to the ion compositions (bulk densities of sulphuric acid $\left(1840 \mathrm{~kg} \mathrm{~m}^{-3}\right)$ and ammonium bisulphate $\left(1780 \mathrm{~kg} \mathrm{~m}^{-3}\right)$, $1500 \mathrm{~kg} \mathrm{~m}^{-3}$ for dimethylamine-sulphuric acid clusters, and $1400 \mathrm{~kg} \mathrm{~m}^{-3}$ for clusters containing also other organics). An HR-ToF-AMS (Aerodyne Research, Inc., Billerica, MA, USA) was used for the on-line characterisation of the chemical composition of particles larger than $50 \mathrm{~nm}$. A detailed description can be found elsewhere (DeCarlo et al., 2006). Mass concentrations (Allan et al., 2004) and elemental O:C and $\mathrm{H}: \mathrm{C}$ ratios (Aiken et al., 2007, 2008) were calculated 
Table 2. Typical atmospheric inorganic (ammonium sulphate (AS), ammonium bisulphate (AbS), sulphuric acid (SA)) and SOA (with different O:C ratios) compounds hygroscopicities and ethanol affinities. (*extrapolated (from 20-50 nm) from Vaattovaara et al., 2005).

\begin{tabular}{lllll}
\hline Compound & Hygroscopicity $(\kappa)$ & Reference & Ethanol affinity $(\eta)$ & Reference \\
\hline AS & $0.47-0.51$ & Topping et al. (2005); Petters (2007) & 0 & Joutsensaari et al. (2004) \\
AbS & $0.53-0.56$ & Topping et al. (2005); Petters (2007) & $0.02-0.1$ & Vaattovaara et al. (2005) \\
SA & 0.9 & Topping et al. (2005); Petters (2007) & $0.4-0.9^{*}$ & Vaattovaara et al. (2005) \\
SA & 0.7 & Sullivan et al. (2010) & \\
SOA (O:C ratio: 0-1) & $0-0.3$ & Massoli et al. (2010) & & Raatikainen et al. (2010) \\
SOA (O:C ratio: $0.23-0.77)$ & & & $0.12-0.17$ & \\
\hline
\end{tabular}

using the ToF-AMS Analysis v1.51H and ToF-AMS HR Analysis v1.10H toolkits (D. Sueper, U. of Colorado, Boulder, CO, USA) for the Igor Pro 6 (Wavemetrics, Lake Oswego, OR) software package.

\subsection{Volume fractions of organics $\left(\varepsilon_{0}\right)$ and of SA $\left(\varepsilon_{\mathrm{SA}}\right)$}

The volume fraction $\left(\varepsilon_{y}\right)$ of component $y$ in a particle is defined as the volume of this component divided by the total particle volume. The sum of the volume fractions over all $n$ components thus becomes unity by definition:

$$
\sum_{y=1}^{n} \varepsilon_{y}=1
$$

The hygroscopicity $(\kappa)$ of a mixed particle can be calculated in good approximation from the hygroscopicities of the components $\left(\kappa_{y}\right)$ and their respective volume fractions using the Zdanovskii-Stokes-Robinson (ZSR) mixing rule (Petters and Kreidenweis, 2007):

$\kappa=\sum_{y=1}^{n} \varepsilon_{y} \kappa_{y}$

Table 2 presents the hygroscopicities of typical atmospheric compounds. As we can see, the hygroscopicities for the inorganic compounds (SA, AbS, AS) in Table 2 are substantially higher than the ones for organic species. It should be noted that there are two reported kappa vales for SA particles (0.7 and 0.9: Sullivan et al., 2010; Petters and Kreidenweis, 2007). When the theoretical SA kappa value is reduced by the effect of the residual water in the dry particles in HTDMA measurements the value is close to 0.7. Biskos et al. (2009) also reported the reduced hygroscopic properties for the SAparticles smaller than $36.1 \mathrm{~nm}$ based on partial neutralisation because of contaminant $\mathrm{NH}_{3}$ in the experimental HTDMA set-up. Hence, we use the value 0.7 for the kappa value of SA particles (Sullivan et al., 2010). With known O:C ratio the organic hygroscopicity $\left(\kappa_{\mathrm{o}}\right)$ can be explicit from previous measurements by Massoli et al., 2010 (e.g. at O:C 0.1 it is $0.05)$. Using a hygroscopicity of 0.7 for sulphuric acid, the overall (SA, AbS, AS) inorganic hygroscopicity $\left(\kappa_{i}\right)$ is in the narrow range from $\sim 0.5$ to 0.7 . Thus, it is possible to estimate the organic volume fraction to a good approximation from the measured kappa of the mixed particles even if the acidity is unknown.

Now we can estimate the volume fraction of organics $\left(\varepsilon_{0}\right)$ from Eqs. (5) and (6) by assuming a "two-component" particle consisting of organics (o) and inorganic sulphates (i):

$\varepsilon_{\mathrm{O}}=\frac{\left(\kappa-\kappa_{\mathrm{i}}\right)}{\left(\kappa_{\mathrm{o}}-\kappa_{\mathrm{i}}\right)}$

where $\kappa$ is the combined overall (measured) hygroscopicity, $\varepsilon_{i}$ and $\kappa_{\mathrm{i}}$ are the volume fraction and hygroscopicity parameter for sulphates and $\varepsilon_{\mathrm{o}}$ and $\kappa_{\mathrm{o}}$ the volume fraction and hygroscopicity parameter for organic compounds.

The ZSR-mixing rule (Eq. 5), which neglects solutesolute interactions, can also be applied to calculate the overall aerosol particle ethanol affinity $(\eta)$ from the ethanol affinities of the components $\left(\eta_{y}\right)$ and their respective volume fractions:

$\eta=\sum_{y=1}^{n} \varepsilon_{y} \eta_{y}$

The ethanol affinities for the inorganic sulphates (AS, AbS, SA) and organics (SOA) are listed in Table 2. The ethanol affinities of AS, AbS and organics are all low, which makes it impossible to distinguish between these components based on an OTDMA measurement alone. On the other hand, the ethanol affinity of SA is substantially higher than that of AS and $\mathrm{AbS}$. This makes it possible, with independent knowledge of the organic volume fraction from Eq. (7), to estimate the acidity (sulphuric acid volume fraction) of the particles from the OTDMA measurement. If we assume a "three-component" particle consisting of organics (o), sulphuric acid (SA) and the other inorganic sulphates (x; comprising AS and $\mathrm{AbS}$ ), we can insert $\varepsilon_{x}=1-\varepsilon_{\mathrm{o}}-\varepsilon_{\mathrm{SA}}$ (from Eq. 5) into Eq. (8) and solve it for $\varepsilon_{\mathrm{SA}}$ :

$\varepsilon_{\mathrm{SA}}=\frac{\varepsilon_{0} \eta_{0}+\eta_{x}-\varepsilon_{0} \eta_{x}-\eta}{\eta_{x}-\eta_{\mathrm{SA}}}$

where $\eta_{\mathrm{SA}}(0.4-0.9), \eta_{x}(0-0.1)$ and $\eta_{\mathrm{o}}(0.12-0.17)$ are taken from Table 2, $\varepsilon_{\mathrm{o}}$ is determined from the HTDMA measurement (Eq. 7) and $\eta$ is the measured ethanol affinity of the mixed particle. These ranges of the ethanol affinity produce the uncertainty for the approximated $\varepsilon_{\mathrm{SA}}$. 


\subsection{Particle composition calculations by E-AIM model}

In addition to our experimental approach, the thermodynamic equilibrium model E-AIM, Extended Aerosol Inorganic Model (Wexler and Clegg, 2002; Clegg et al., 1998, 2001; Ge et al., 2011; http://www.aim.env.uea.ac.uk/aim/ aim.php), was also used to calculate the size-dependent composition of particles. The particles were assumed to be aqueous solutions in the model calculations and hence only gas and aqueous phases were considered in E-AIM. In general, for this kind of system, E-AIM calculates the equilibrium composition for the aqueous and gas phases based on the total concentrations of each of the compounds to account for dissociation and protonation in the aqueous phase. Here, EAIM was used iteratively to calculate the composition of the non-organic fraction based on the measured $\mathrm{RH}$ and the measured organic fraction, particle size, and gas phase concentrations of ammonia and DMA.

To determine the size-dependent composition of the inorganic fraction, organic fraction derived from hygroscopicity measurements made with the HTDMA as a function of particle size was used. This organic fraction was assumed to contain PD and/or its oxidation products condensed onto the particle. The remaining volume of the particle, here denoted as non-organic fraction, therefore consisted of sulphuric acid, ammonia, dimethylamine and water, and/or their ions. The contributions of sulphuric acid, ammonia, DMA and water to the non-organic fraction of the particle were calculated iteratively with E-AIM by finding the particle composition for which ammonia, DMA and water were in gas-liquid equilibrium with the measured gas phase concentrations and RH. This approach includes the assumption that ammonia, DMA and water, due to their higher gas phase concentrations, smaller molar masses, or shorter diffusion time scales, diffuse fast enough to maintain gas-liquid equilibrium while sulphuric acid and organic compounds condense on the particle.

E-AIM considers planar surfaces and, to take surface curvature into account for the gas-liquid equilibrium, the Kelvin effect was included in the iteration process by assuming a surface tension of $50 \mathrm{mN} \mathrm{m}^{-1}$. The particle density was assumed to be $1500 \mathrm{~kg} \mathrm{~m}^{-3}$. The PD and its oxidation products were treated as one non-dissociating organic compound with molar mass of $170 \mathrm{~g} \mathrm{~mol}^{-1}$ (molar mass of PD) and with activity coefficient of unity, i.e. ideal mixture assumption. Therefore, the interactions between this organic compound and the rest of the compounds were minimised. The activity coefficient of dimethylamine was calculated using the UNIFAC standard set of parameters, and for the other dimethylamine properties, the values provided in the E-AIM compound library were used (Ge et al., 2011a, b).

The results of the model calculations were the fractions of sulphuric acid, ammonia, DMA and water and/or their dissociation/protonation products in the non-organic fraction of the particle. The composition predicted from the model was used to derive the $\kappa$ and $\eta$ of the particles using ZRSapproach (Eqs. 5 and 6) with the inorganic and organic $\kappa$ or $\eta$ described in Sects. 2.4 and 2.5.

\section{Results and discussion}

\subsection{Particle composition in the presence of sulphuric acid and ammonia in the chamber}

Here we present the measurements with sulphuric acid and ammonia in the CLOUD chamber (Run A, Table 1). The gas concentrations measured in the chamber are shown in Table 1. Here the UVS was turned on at 10:10LT, which immediately caused nucleation and high particle growth rates (Fig. 1a). At the start of the nucleation, we can see from the APi-TOF measurements (Fig. 1b) that initially there were pure SA clusters below the size of $1.2 \mathrm{~nm}$ with four SA molecules. At larger cluster sizes from 1.2 to $1.9 \mathrm{~nm}$ (4-19 molecules), a fraction of the $\mathrm{SA}$ was associated with $\mathrm{NH}_{3}$.

Figure $1 \mathrm{c}$ and $\mathrm{d}$ show the measured (stars) hygroscopic $(\mathrm{C})$ and ethanol (D) growth factors (Eq. 1) as a function of the saturation ratio for the selected dry diameter of $150 \mathrm{~nm}$. The measured HGF curve features a clear deliquescence (DRH) point at RH $\sim 78 \%$, which matches well with theoretical and measured values for ammonium sulphate (Fig. 1c dashed grey line, Hämeri et al., 2000; Gysel et al., 2002). In addition, the measured growth factors below and above the DRH values are in a very good agreement with theoretical values calculated for $150 \mathrm{~nm}$ ammonium sulphate particles. For comparison, the calculated growth factors for sulphuric acid particles (Topping et al., 2005) are also shown in Fig. 1c and d. The deviation from the measured growth factors is obvious: for sulphuric acid particles, there is no clear DRH point, and the theoretical HGF values are also considerably higher than the measured values (see Fig. 1d, dashed black line). Based on the O-TDMA measurements, the particles did not grow in subsaturated ethanol vapour, as shown in Fig. 2b. Based on measurements by Vaattovaara et al. (2005), the sulphuric acid particles have an EGF larger than 1.3 at 0.8 ethanol saturation ratio (Fig. 1d, grey dashed line). Therefore, both OTDMA measurements and H-TDMA measurements confirm that the particles produced in these conditions consisted of ammonium sulphate at a diameter of $150 \mathrm{~nm}$. These results are in good agreement with earlier studies, as the particles formed by nucleation eventually become chemically neutral and form salt particles, such as ammonium bisulphate and ammonium sulphate if the ammonia concentration is high enough (Seinfeld and Pandis, 1998; Kim et al., 1998). 
A)
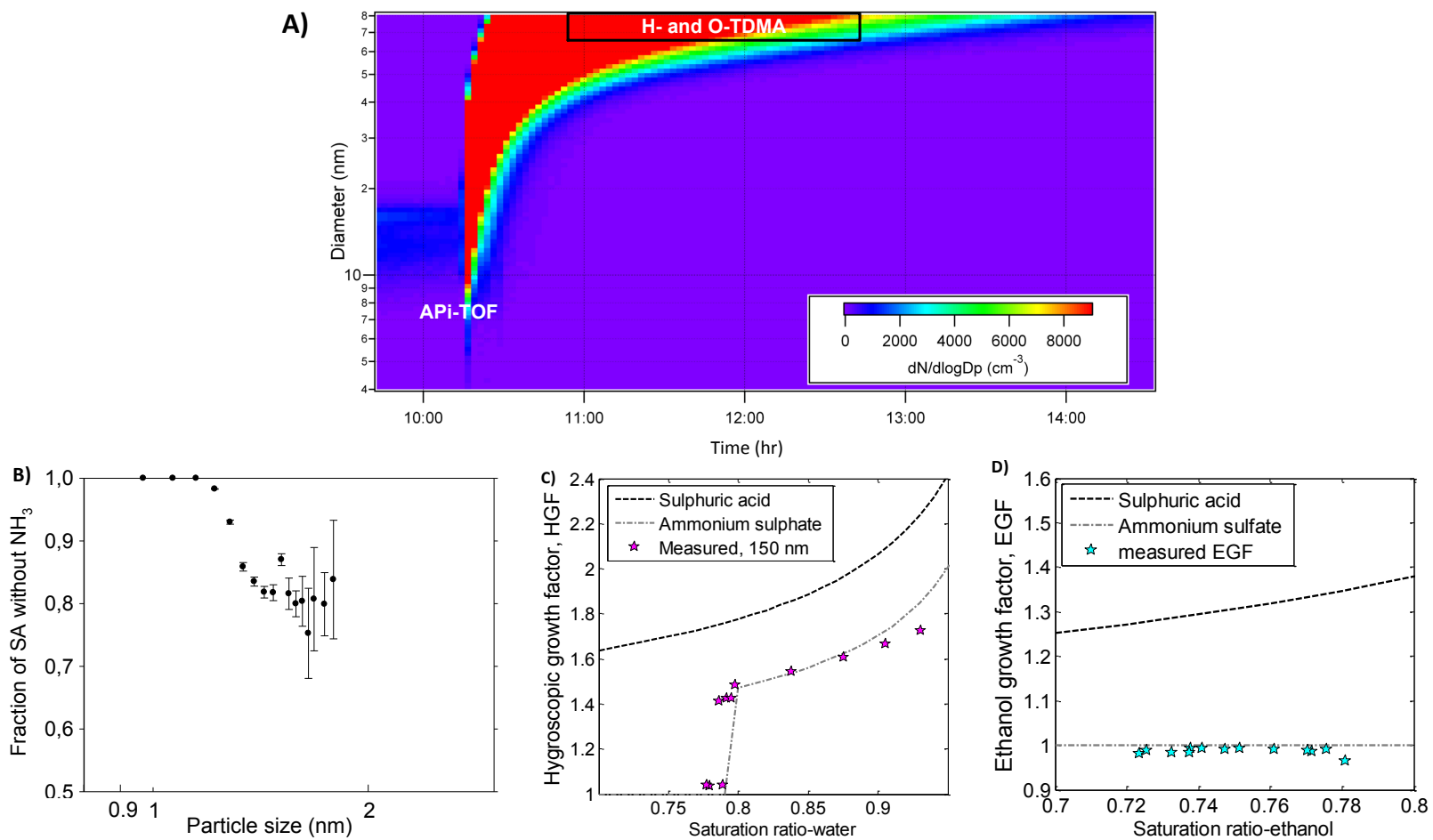

Fig. 1. Experimental (A) time evolution of particle size distribution measured by the SMPS; (B) mass fraction of SA ions without $\mathrm{NH}_{3}$ binding, which decreases with increasing cluster size (APi-TOF) in beginning of the nucleation; hygroscopic (C) and ethanol (D) growth factors (stars) versus relative humidity or ethanol saturation ratio from $\mathrm{SA}+\mathrm{UVS}+\mathrm{NH}_{3}$ run. The particle size in the TDMA measurements was $150 \mathrm{~nm}$. The theoretical sulphuric acid (black dashed line) and ammonium sulphate (grey dotted line) growth factors versus relative humidity/ethanol saturation ratio are also presented. The timing of the APi-TOF and growth factor measurements is marked in (A), which depicts the time evolution of the particle size distribution.

\subsection{Particles produced in the presence of organics}

\subsubsection{Composition of particles produced in the presence of pinanediol (PD) with a high intensity UV source}

In this section, we present the TDMA and CCNC results for particles formed in the presence of sulphuric acid, ammonia and organics (oxidation products of $\mathrm{PD}$ ) with strong UV light (Run B in Table 1). At the beginning of the experiment, the high intensity UV light source was turned on. The nucleated clusters $(\sim 2 \mathrm{~nm})$ had a high organic mass fraction of $75 \pm 10 \%$ right after the UV was switched on, based on measurements from the API-TOF. This experiment resulted in fast growth (GR $=84 \mathrm{~nm} \mathrm{~h}-1$ for mobility diameters of 47 to $80 \mathrm{~nm}$ ) of the nucleated particles (Fig. 2a). The hygroscopicities measured by the H-TDMA and CCNC were quite stable during the analysis period, as can be seen in Fig. 2b. The kappa values derived from the H-TDMA and CCN results were $0.11 \pm 0.02$ and $0.14 \pm 0.01$, respectively. The O:C ratio derived from the AMS (mass distribution mode diameter of $110 \mathrm{~nm}$ ) was also stable during the run, with a value of $0.365 \pm 0.002$. The organic mass fraction of these particles derived from the AMS results was high $(99.7 \%)$. It can therefore be assumed that the organic fraction dominates the hygroscopic behaviour of the particles. Indeed, the hygroscopicity of these particles is in good agreement with earlier observations of organics particles: the measured $\kappa_{\mathrm{O}}$ is close to the values of $0.07 \pm 0.02$ (H-TDMA, Massoli et al., 2010), $0.04 \pm 0.02$ (H-TDMA, Duplissy et al., 2011) and $0.1 \pm 0.05$ (CCN, Frosch et al., 2011) for oxidation products having an $\mathrm{O}: \mathrm{C}$ ratio of 0.37 .

\subsubsection{Size-dependent composition of the particles produced in the presence of pinanediol}

Next, we investigate the composition of the particles produced in the chamber in the presence of pinanediol, $\mathrm{NH}_{3}$, dimethylamine, SA, fibre optic UV and galactic cosmic rays (Table 1, Run C). The composition analysis presented in this section is based on H-TDMA, CCNC, O-TDMA, APi-TOF, SMPS (GR-analysis) and AMS measurements.

In Fig. 3, the evolution of the measured number size distributions during the experiment including several nucleation events is shown. The studied particle nucleation event (Fig. 3, Table 1, Run C) has a growth rate of $\mathrm{GR}=3.24 \mathrm{~nm} \mathrm{~h}^{-1}$ for particles with mobility diameter of 26-40 nm, and GR $=3.8 \mathrm{~nm} \mathrm{~h}^{-1}$ for particles with mobility diameter of $41-60 \mathrm{~nm}$. The TDMA and CCNC results 

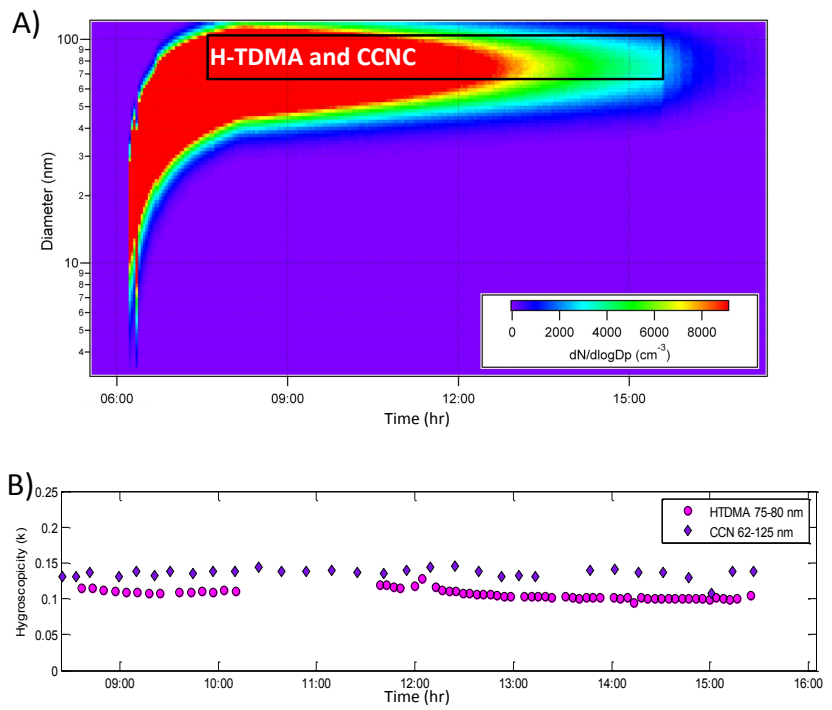

Fig. 2. (a) Evolution of the particle size distribution in the CLOUD chamber in the presence of sulphuric acid and pinanediol and UVS (Run B, Table 1). (b) Hygroscopicities measured by the H-TDMA and the CCNC.

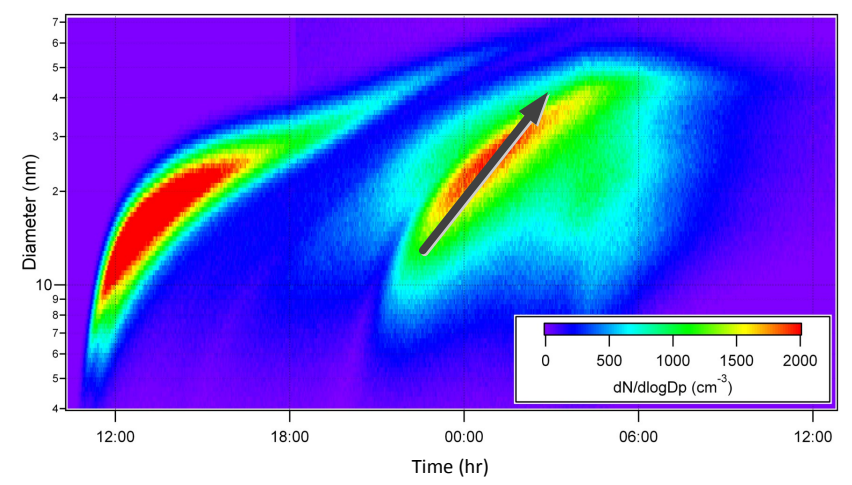

Fig. 3. The evolution of the particle size distribution in the presence of sulphuric acid, ammonia, dimethylamine and pinanediol in the CLOUD chamber. The event studied in detail (Run C, Table 1) is marked by an arrow.

presented here were measured during the intensive growth period $(15-30 \mathrm{~nm})$ and under more stable conditions (50$80 \mathrm{~nm})$. The measurements reported here were carried out during Run C, which has been marked with an arrow in Fig. 3 (Table 1, Run C).

First, we investigate the hygroscopic and ethanol growth factors of particles of $30 \mathrm{~nm}$ diameter measured by the $\mathrm{H} / \mathrm{O}$ TDMA for water or ethanol saturation ratios of $0.4-0.9$ and 0.2-0.9, respectively (Fig. 4). For comparison, the theoretical and experimental growth curves in water and ethanol for sulphuric acid (black dashed lines, Joutsensaari et al., 2001; Vehkamäki et al., 2002; Vaattovaara et al., 2005), ammonium bisulphate (black solid lines, Joutsensaari et al., 2004; Tang et al., 1994) and ammonium sulphate (grey dashed lines, Hämeri et al., 2000; Joutsensaari et al., 2001) are also presented (Fig. 4a). Instead of the clear deliquescence point observed in the presence of high ammonia background (Fig. 1c), a smooth growth curve was now measured for water vapour saturation ratios from $S=0.4$ to 0.98 (Fig. 4 a). It has recently been found that, if the particles contain "high" mass fractions of organics and $\mathrm{O}: \mathrm{C}$ ratios below 0.7 , only a slightly shifted deliquescence point should be visible in the growth curve, indicating liquid-liquid phase separation of the organic-inorganic phases (Smith et al., 2011; Bertram et al., 2012). However, Meyer et al. (2009) and Smith et al. (2012) observed that with high mass fractions of SOA on AS seed particles, the DRH dropped remarkably (even at $S=0.4$ ). It should be noted that in the results presented by Smith et al. (2012), the O:C ratio of the studied particles was high ( $>0.7)$. For pure AbS the deliquescence point would be at $S=0.4$, which is at the lowest limit for the measurements being presented, while SA particles have a smooth growth curve as shown in Fig. 4a. According to the AMS measurements, the $\mathrm{O}: \mathrm{C}$ ratios of the formed particles were around $0.20( \pm 0.05)$. Raatikainen et al. (2010) measured HGFs around 1 for SOA with comparable O:C ratios (green point in Fig. 4a). The measured HGF values at $\mathrm{RH}=90 \%$ fall between those of pure inorganic salts and pure SOA particles having an $\mathrm{O}: \mathrm{C}$ ratio around 0.2 . The shape of the growth curve and the HGF values measured at $\mathrm{RH}=90 \%$ indicate that the particles' hygroscopic growth factor is most probably the result of mixed SA/AS/AbS/Org growth factors. Besides ammonium salts, these particles can also include small amount salts from dimethylamine and SA, clusters of which were detected by the APi-TOF (in Run C, Table 1).

To obtain further information on the chemical composition of the particles, we also investigated the ethanol growth factors (EGF) of the particles. The EGF results (Fig. 4b) also showed a smooth growth curve comparable to the HGF behaviour (Fig. 4a). For comparison, the experimental and theoretical EGF values with increasing ethanol saturation ratio for SA, AbS and AS are shown in Fig. 4b. We also extrapolated the EGF value for SA particles (at an ethanol saturation ratio of 0.8) from the EGF measurements for particles composed of a mixture of AbS/SA (Vaattovaara et al., 2005). The extrapolated value (Fig. 4b, black diamond) is very close to the calculated theoretical value. According to the study of Raatikainen et al. (2010), boreal forest field measurements show EGF values of 1.16 and 1.12 for organic fractions with $\mathrm{O}: \mathrm{C}$ ratios of 0.23 and 0.77 , respectively (green squares in Fig. 4b). Thus, the oxidation level of organics has only a minor effect on the ethanol growth factor.

The EGF values measured here are greater than values predicted for pure AbS (Vaattovaara et al., 2005) and near the values predicted for organics (having O:C ratios comparable to the studied particles, Raatikainen et al., 2010; Vaattovaara et al., 2009) but clearly below values for SA. The results from the performed EGF measurements support the conclusion 
A)

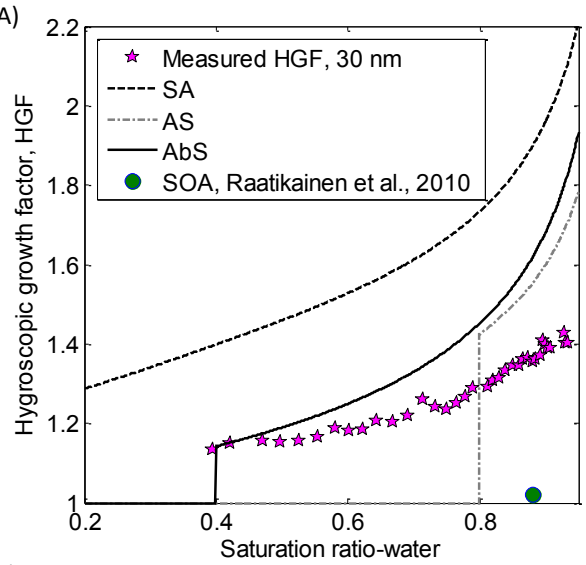

B)

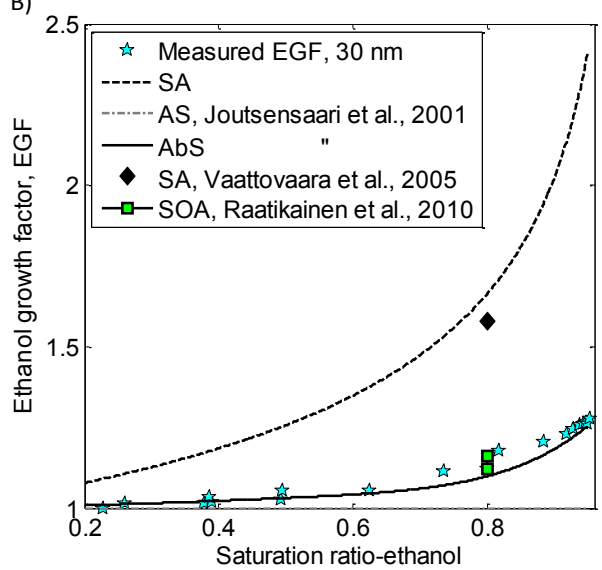

Fig. 4. Hygroscopic (A) and ethanol (B) growth factor versus saturation ratio for $30 \mathrm{~nm}$ particles from pinanediol runs (Run C, in Table 1). Stars indicate values measured in this study, while lines show theoretical and measured values for pure compounds, and green squares and circles give values for an organic fraction with a similar O:C ratio as obtained in this experiment (Massoli et al. (2011); Raatikainen et al. (2010) (measured for particle diameter of $50 \mathrm{~nm}$ ) and the black diamond shows the value for SA (extrapolated from $50 \mathrm{~m} \% \mathrm{H}_{2} \mathrm{SO}_{4}$ at $30 \mathrm{~nm}$ Vaattovaara et al., 2005).

drawn from the H-TDMA measurement: $30 \mathrm{~nm}$ particles most probably consist of a mixture of SA/AS/AbS/Org.

To obtain further insight into the particle composition, we analyse the volume fraction of organics and SA in the different particle size ranges using the method described in Sect. 2.4. The $\kappa$ and $\eta$ values derived from H-TDMA and O-TDMA measurements versus particle diameter are shown in Fig. 5a: $\kappa$ decreases from 0.4 at $15 \mathrm{~nm}$ to 0.13 at $63 \mathrm{~nm}$. The decreasing $\kappa$ value indicates that the organic fraction (the less hygroscopic fraction) increases with particle size. As can be seen in Fig. 5a, the ethanol affinity $\eta$ derived from OTDMA measurements does not depend on the particle size: the $\eta$ values for 15,30 and $50 \mathrm{~nm}$ size particles are $0.19,0.2$ and $0.2 \pm 0.02$, respectively.

The organic volume fraction in the particles can be approximated using the hygroscopicity $\kappa$ values for pure substances
A)
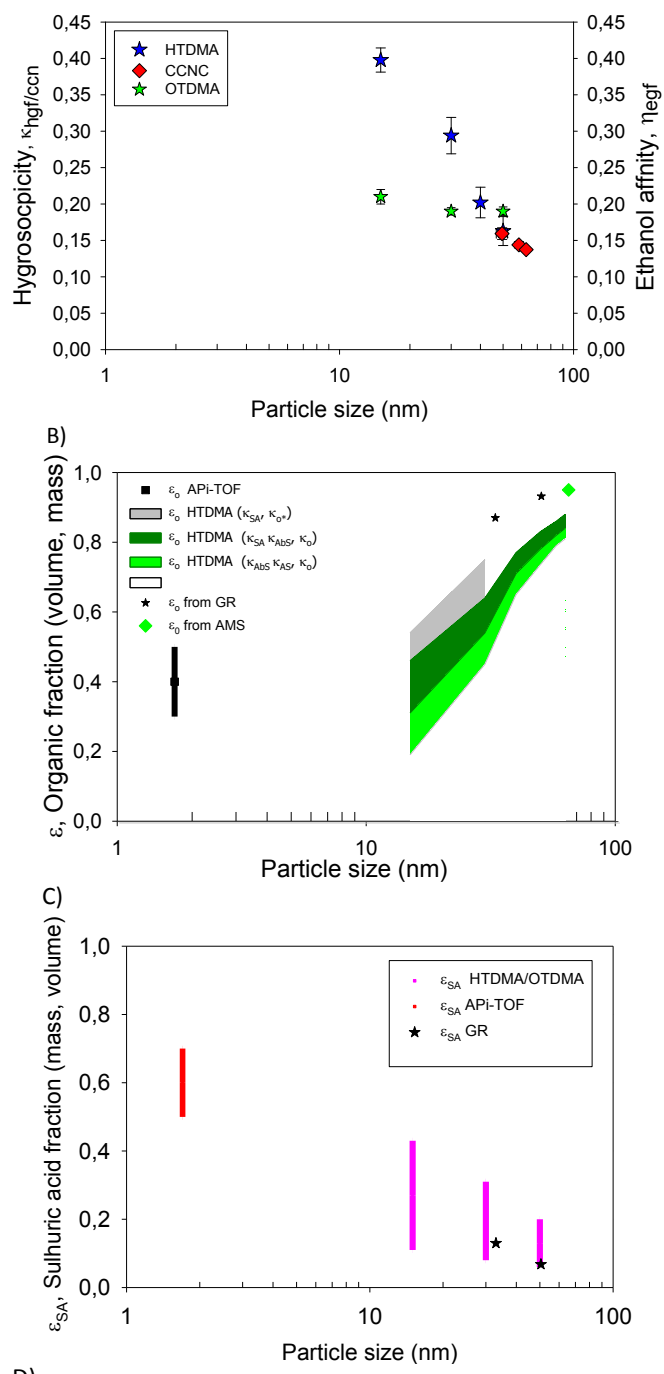

D)

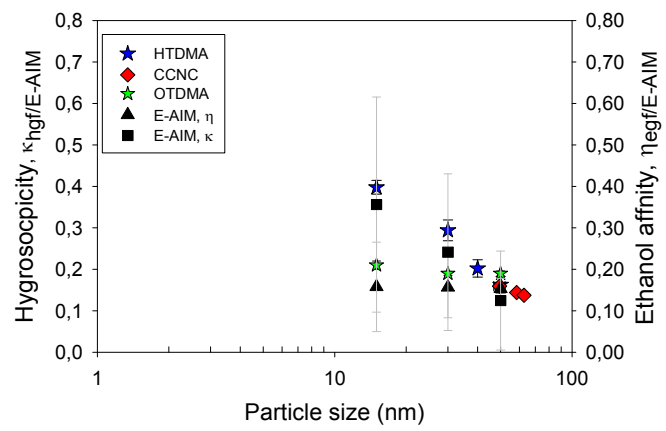

Fig. 5. (A) Measured hygroscopicities and ethanol affinities; (B) approximated organic fraction from the H-TDMA/CCNC, AMS (for aerodynamic diameter) $\left(\varepsilon_{\mathrm{o}}, \mathrm{vol} \%\right)$, and GF measurements $\left(\varepsilon_{\mathrm{O}}\right.$, $\left.\mathrm{nm} \mathrm{h}^{-1}\right)$; (C) SA vol \% in the particles versus particle size in presence of PD; and (D) hygroscopicities and ethanol affinities; experimental results and values predicted from the composition using the E-AIM model. 
together with the ZSR approach. The $\kappa$ values at $\mathrm{RH}=90 \%$ for pure $\mathrm{SA}, \mathrm{AbS}$ and $\mathrm{AS}$ are 0.7, 0.56 and 0.47, respectively, where the values for AS and AbS are derived from hygroscopic growth as modelled by Topping et al. (2005) and the value for SA is measured by Sullivan et al. (2010) (Table 2). In addition, to calculate the volume fraction of organics $\varepsilon_{\mathrm{O}}$ from Eq. (7), we also need to estimate $\kappa_{0}$. The basic assumption we make is that neither the $\mathrm{O}: \mathrm{C}$ ratio nor $\kappa_{\mathrm{o}}$, is affected by the particle size (the O:C of the particles at $\sim 65 \mathrm{~nm}$ was approximately 0.2 according to the AMS analysis). To test the sensitivity of our results to this assumption, we varied the $\mathrm{O}: \mathrm{C}$ ratio of the organic fraction of 15 and $30 \mathrm{~nm}$ particles from 0.2 to $0.5\left(\kappa_{\mathrm{o}}\right.$ varied from 0.05 to 0.14 for $\alpha$-pinene oxidation products in Massoli et al., 2010). The areas in Fig. 5b represent the uncertainty of the analysis resulting from the uncertainty in the input values of $\kappa_{i}$ and $\kappa_{\mathrm{o}}$ used in Eq. (7): for $\kappa_{i}$ we assume that particles consist of either SA or AbS or AS, i.e. $\kappa_{i}$ varies from 0.47 to 0.7 . The maximum changes in the calculated organic volume fractions caused by the above uncertainties are from 0.2 to 0.6 for $15 \mathrm{~nm}$ particles and 0.8 to 0.9 for $63 \mathrm{~nm}$ particles. These results are consistent with both the AMS finding which gave an organic volume fraction of 0.95 for particles with diameter $65 \mathrm{~nm}$ (Fig. 5b, diamond), and with the organic fraction derived from the GR analysis (Fig. 5b, stars). At the beginning of the nucleation event, the organic mass fraction of sub- $2 \mathrm{~nm}$ (ca. $1.7 \mathrm{~nm}$ ) clusters was in the range of $0.3-0.5$, as derived from the analysis of APi-TOF data. These results (Fig. 5b) indicate that the organic fraction gradually increases with size. Our results are in agreement with several studies, made in chambers and in the field, showing that the condensation of organics contributes to the particle growth process (Riipinen et al., 2012; Jimenez et al., 2009; Riccobono et al., 2012; Vaattovaara et al., 2009; Laaksonen et al., 2008).

Next, we use the derived organic fraction shown in Fig. 5b to estimate the distribution of un-neutralised SA in the particles by following the procedure described in Sect. 2.4 (Eq. 8). The results are shown in Fig. 5c (pink bars). The width of the coloured bars represents the uncertainty of the method resulting from the uncertainties of the estimated organic fractions presented in Fig. 5b. As can be seen, the SA fraction clearly decreases with increasing particle size, which is to be expected based on the comparison with the APi-TOF (Fig. 5c, red bar) and GR analysis (Fig. 5c, stars). It is important to note that the simple experimental approach used to analyse the composition of the inorganic fraction is not comprehensive as it only includes SA, AS and AbS. In fact, aminium salts are also likely to be present even with very low concentrations (Table 1). For comparison, the hygroscopicity and ethanol affinity derived from the measurements and calculated based on the non-organic composition predicted with E-AIM are shown in Fig. 5d. The error limits in the results derived from the modelled composition are caused by the organic volume fraction insensitivity shown in Fig. 5b and the uncertainty of the SA ethanol affinity. However, the re- sults from the E-AIM model and experiments are comparable. Thus, the non-organic composition derived from the measurements by ZSR-approximation is quite well in line with the modelled values.

Overall, the size-dependent composition analysis made here provides valuable information about the sulfate and organic contribution to nanoparticle growth. According to our analysis, the particles consists mostly of SA right after nucleation, but the inorganic fraction gradually decreases with particle growth (Fig. 5c), while the organic fraction increases (Fig. 5b). There are two possible explanations: (1) the Kelvin effect inhibits the condensation of all organic condensable molecules at the smallest sizes; and (2) the gas phase concentrations of sulphuric acid and condensable organics have different time scales (Pierce et al., 2011; Donahue et al., 2011). As the precursors of both sulphate and condensable organics are produced primarily via reactions with $\mathrm{OH}$, and the temporal profiles of the precursors in the chamber are similar (Table 1, Run C), in our case the former explanation is more likely. However, without knowing the exact chemical pathways which produce the condensable organic, it is difficult to be certain about this.

\section{Conclusions}

The evolution of the particle chemical composition in CLOUD nucleation experiments in the presence of sulphuric acid, ammonia, dimethylamine and oxidation products of pinanediol was studied by analysing the cluster-ion composition, hygroscopicity, ethanol affinity and oxidation state of the formed particles. In the presence of relatively high concentrations of sulphuric acid and ammonia, the particles started to neutralise in the small cluster stage, resulting in pure AS at the size of $150 \mathrm{~nm}$. It is notable that these measurements indicate that large particles of pure ammonium sulphate were nucleated and grown in the CLOUD chamber from the vapour phases - implying a strict 2:1 molar ratio of $\mathrm{NH}_{3}: \mathrm{H}_{2} \mathrm{SO}_{4}$ was maintained during the entire growth process. In the presence of organics the particles' organic fraction increased from 0.3 to close to 1 as they grew from 2 to $65 \mathrm{~nm}$ in diameter. Furthermore, the particle acidity clearly decreased as the particle grew from 15 to $50 \mathrm{~nm}$. The hygroscopicities and ethanol affinities derived from the composition predicted with the E-AIM model agreed well with the experimentally-measured values. We have demonstrated that, by combining HTDMA and OTDMA analyses, it is possible to gain information on the composition of the nucleated particle during their growth in the "intermediate" size range between the Api-ToF and AMS measurement range.

Acknowledgements. We would like to thank CERN for supporting CLOUD with important technical and financial resources, and for providing a particle beam from the CERN Proton Synchrotron. This research has received funding from the EC Seventh Framework 
Programme (Marie Curie Initial Training Network "CLOUD-ITN" grant no. 215072, the ERC-Advanced grant "ATMNUCLE" (no. 227463), the German Federal Ministry of Education and Research (project no. 01LK0902A), the Swiss National Science Foundation (project nos. 206621_125025 and 206620_130527), the Academy of Finland Centre of Excellence program (project no. 1118615), Academy of Finland (project no. 138951), the Austrian Science Fund (FWF; project nos. P19546 and L593), the Portuguese Foundation for Science and Technology (project no. CERN/FP/116387/2010), the US National Science Foundation, and the Russian Foundation for Basic Research (grant N08-02-91006CERN).

Edited by: J. H. Seinfeld

\section{References}

Aiken, A. C., DeCarlo, P. F., and Jimenez, J. L.: Elemental analysis of organic species with electron ionization high-resolution mass spectrometry, Anal. Chem., 79, 8350-8358, 2007.

Aiken, A. C., Decarlo, P. F., Kroll, J. H., Worsnop, D. R., Huffman, J. A., Docherty, K. S., Ulbrich, I. M., Mohr, C., Kimmel, J. R., Sueper, D., Sun, Y., Zhang, Q., Trimborn, A., Northway, M., Ziemann, P. J., Canagaratna, M. R., Onasch, T. B., Alfarra, M. R., Prevot, A. S. H., Dommen, J., Duplissy, J., Metzger, A., Baltensperger, U., and Jimenez, J. L.: O/C and OM/OC ratios of primary, secondary, and ambient organic aerosols with high-resolution time-of-flight aerosol mass spectrometry, Environ. Sci. Technol., 42, 4478-4485, 2008.

Allan, J. D., Delia, A. E., Coe, H., Bower, K. N., Alfarra, M. R., Jimenez, J. L., Middlebrook, A. M., Drewnick, F., Onasch, T. B., Canagaratna, M. R., Jayne, J. T., and Worsnop, D. R.: A generalised method for the extraction of chemically resolved mass spectra from aerodyne aerosol mass spectrometer data, J. Aerosol Sci., 35, 909-922, 2004.

Bianchi, F., Dommen, J., Mathot, S., and Baltensperger, U.: Online determination of ammonia at low pptv mixing ratios in the CLOUD chamber, Atmos. Meas. Tech., 5, 1719-1725, doi:10.5194/amt-5-1719-2012, 2012.

Biskos, G., Buseck, P. R., and Martin, S. T.: Hygroscopic growth of nucleation-mode acidic sulfate particles, Aerosol Sci., 40, 338347, 2009.

Bertram, A. K., Martin, S. T., Hanna, S. J., Smith, M. L., Bodsworth, A., Chen, Q., Kuwata, M., Liu, A., You, Y., and Zorn, S. R.: Predicting the relative humidities of liquid-liquid phase separation, efflorescence, and deliquescence of mixed particles of ammonium sulfate, organic material, and water using the organic-to-sulfate mass ratio of the particle and the oxygen-tocarbon elemental ratio of the organic component, Atmos. Chem. Phys., 11, 10995-11006, doi:10.5194/acp-11-10995-2011, 2011.

Carslaw, K. S., Boucher, O., Spracklen, D. V., Mann, G. W., Rae, J. G. L., Woodward, S., and Kulmala, M.: A review of natural aerosol interactions and feedbacks within the Earth system, Atmos. Chem. Phys., 10, 1701-1737, doi:10.5194/acp-10-17012010, 2010.

Claeys, M., Graham, B., Vas, G., Wang, W., Vermeylen, R., Pashynska, V., Cafmeyer, J., Guyon, P., Andreae, M. O., Artaxo, P., and Maenhaut, W.: Formation of secondary organic aerosols through photooxidation of isoprene, Science, 303, 1173-1176, 2004.
Clegg, S. L., P. Brimblecombe and A. S. Wexler: A thermodynamic model of the system $\mathrm{H}^{+}-\mathrm{NH}_{4}^{+}-\mathrm{SO}_{4}^{2-}-\mathrm{NO}_{3}^{-}-\mathrm{H}_{2} \mathrm{O}$ at tropospheric temperatures. J. Phys. Chem. A, 102, 2137-2154, 1998.

Clegg, S. L., Seinfeld, J. H., and Brimblecombe, P.: Thermodynamic modelling of aqueous aerosols containing electrolytes and dissolved organic compounds, J. Aerosol Sci., 32, 713-738, 2001.

DeCarlo, P. F., Kimmel, J. R., Trimborn, A., Northway, M. J., Jayne, J. T., Aiken, A. C., Gonin, M., Fuhrer, K., Horvath, T., Docherty, K. S., Worsnop, D. R., and Jimenez, J. L.: Field-deployable, high-resolution, time-of-flight aerosol mass spectrometer, Anal. Chem., 78, 8281-8289, 2006.

Donahue, N. M., Trump, E. R., Pierce, J. R., and Riipinen, I.: Theoretical Constraints on Pure Vapor-Pressure Driven Condensation of Organics to Ultrafine Particles, Geophys. Res. Lett., 38, L16801, doi:10.1029/2011GL048115, 2011.

Duplissy, J., Enghoff, M. B., Aplin, K. L., Arnold, F., Aufmhoff, H., Avngaard, M., Baltensperger, U., Bondo, T., Bingham, R., Carslaw, K., Curtius, J., David, A., Fastrup, B., Gagné, S., Hahn, F., Harrison, R. G., Kellett, B., Kirkby, J., Kulmala, M., Laakso, L., Laaksonen, A., Lillestol, E., Lockwood, M., Mäkelä, J., Makhmutov, V., Marsh, N. D., Nieminen, T., Onnela, A., Pedersen, E., Pedersen, J. O. P., Polny, J., Reichl, U., Seinfeld, J. H., Sipilä, M., Stozhkov, Y., Stratmann, F., Svensmark, H., Svensmark, J., Veenhof, R., Verheggen, B., Viisanen, Y., Wagner, P. E., Wehrle, G., Weingartner, E., Wex, H., Wilhelmsson, M., and Winkler, P. M.: Results from the CERN pilot CLOUD experiment, Atmos. Chem. Phys., 10, 1635-1647, doi:10.5194/acp-101635-2010, 2010.

Duplissy, J., DeCarlo, P. F., Dommen, J., Alfarra, M. R., Metzger, A., Barmpadimos, I., Prevot, A. S. H., Weingartner, E., Tritscher, T., Gysel, M., Aiken, A. C., Jimenez, J. L., Canagaratna, M. R., Worsnop, D. R., Collins, D. R., Tomlinson, J., and Baltensperger, U.: Relating hygroscopicity and composition of organic aerosol particulate matter, Atmos. Chem. Phys., 11, 11551165, doi:10.5194/acp-11-1155-2011, 2011.

Ehn, M., Junninen H., Schobesberger, S., Manninen, H. E., Franchin, A., Sipilä, M., Petäjä, T., Kerminen, V.-M., Tammet, H., Mirme, A., Mirme, S., Hõrrak, U., Kulmala, M., and Worsnop, D. R.: An instrumental comparison of mobility and mass measurements of atmospheric small ions, Aerosol Sci. Technol., 45, 522-532, 2011.

Frosch, M., Bilde, M., DeCarlo, P., Jurányi, Z., Tritscher, T., Dommen, J., Donahue, N. M., Gysel, M., Weingartner, E., and Baltensperger, U.: Relating cloud condensation nuclei activity and oxidation level of $\alpha$-pinene secondary organic aerosols. J. Geophys. Res., 116, D22212, doi:10.1029/2011JD016401, 2011.

Ge, X., Wexler, A. S., and Clegg, S. L.: Atmospheric amines - Part I. A review, Atmos. Environ., 45, 524-546, 2011 a.

Ge, X., Wexler, A. S., and Clegg, S. L.: Atmospheric amines - Part II. Thermodynamic properties and gas/particle partitioning. Atmos. Environ., 45, 561-577, 2011b.

Gysel, M., Weingartner, E., and Baltensperger, U.: Hygroscopicity of aerosol particles at low temperatures. 2. Theoretical and experimental hygroscopic properties of laboratory generated aerosols, Environ. Sci. Technol., 36, 63-68, doi:10.1021/es010055g, 2002.

Hallquist, M., Wenger, J. C., Baltensperger, U., Rudich, Y., Simpson, D., Claeys, M., Dommen, J., Donahue, N. M., George, C., Goldstein, A. H., Hamilton, J. F., Herrmann, H., Hoff- 
mann, T., Iinuma, Y., Jang, M., Jenkin, M. E., Jimenez, J. L., Kiendler-Scharr, A., Maenhaut, W., McFiggans, G., Mentel, Th. F., Monod, A., Prévôt, A. S. H., Seinfeld, J. H., Surratt, J. D., Szmigielski, R., and Wildt, J.: The formation, properties and impact of secondary organic aerosol: current and emerging issues, Atmos. Chem. Phys., 9, 5155-5236, doi:10.5194/acp-9-51552009, 2009.

Hamed, A., Joutsensaari, J., Mikkonen, S., Sogacheva, L., Dal Maso, M., Kulmala, M., Cavalli, F., Fuzzi, S., Facchini, M. C., Decesari, S., Mircea, M., Lehtinen, K. E. J., and Laaksonen, A.: Nucleation and growth of new particles in Po Valley, Italy, Atmos. Chem. Phys., 7, 355-376, doi:10.5194/acp-7-355-2007, 2007.

Hansel, A., A. Jordan, R. Holzinger, P. Prazeller, W. Vogel, and W. Lindinger: Proton transfer reaction mass spectrometry: on-line trace gas analysis at the ppb level. Int. J. Mass Spectrom. Ion Proc., 149, 609-619, 1995.

Hämeri, K., Väkevä, M., Hansson, H.-C., and Laaksonen, A.: Growth of ultrafine ammonium sulphate aerosol measured using an ultrafine tandem differential mobility analyser, J., Geophys. Res., 105, 22231-22242, doi:10.1029/2000JD900220, 2000.

Jimenez, J. L., Canagaratna, M. R., Donahue, N. M., Prevot, A. S. H., Zhang, Q., Kroll, J. H., DeCarlo, P. F., Allan, J. D., Coe, H., Ng, N. L., Aiken, A. C., Docherty, K. S., Ulbrich, I. M., Grieshop, A. P., Robinson, A. L., Duplissy, J., Smith, J. D., Wilson, K. R., Lanz, V. A., Hueglin, C., Sun, Y. L., Tian, J., Laaksonen, A., Raatikainen, T., Rautiainen, J., Vaattovaara, P., Ehn, M., Kulmala, M., Tomlinson, J. M., Collins, D. R., Cubison, M. J., Dunlea, E. J., Huffman, J. A., Onasch, T. B., Alfarra, M. R., Williams, P. I., Bower, K., Kondo, Y., Schneider, J., Drewnick, F., Borrmann, S., Weimer, S., Demerjian, K., Salcedo, D., Cottrell, L., Griffin, R., Takami, A., Miyoshi, T., Hatakeyama, S., Shimono, A., Sun, J. Y., Zhang, Y. M., Dzepina, K., Kimmel, J. R., Sueper, D., Jayne, J. T., Herndon, S. C., Trimborn, A. M., Williams, L. R., Wood, E. C., Middlebrook, A. M., Kolb, C. E., Baltensperger, U., and Worsnop, D. R.: Evolution of organic aerosols in the atmosphere, Science, 326, 1525-1529, 2009.

Joutsensaari, J., Vaattovaara, P., Vesterinen, M., Hämeri, K., and Laaksonen, A.: A novel tandem differential mobility analyzer with organic vapor treatment of aerosol particles, Atmos. Chem. Phys., 1, 51-60, doi:10.5194/acp-1-51-2001, 2001.

Joutsensaari, J., Toivonen, T., Vaattovaara, P., Vesterinen, M., Vepsäläinen, J., and Laaksonen, A.: Time-resolved growth behavior of acid aerosols in ethanol vapor with a tandem-DMA technique. J. Aerosol Sci., 35, 851-867, 2004.

Junninen, H., Ehn, M., Petäjä, T., Luosujärvi, L., Kotiaho, T., Kostiainen, R., Rohner, U., Gonin, M., Fuhrer, K., Kulmala, M., and Worsnop, D. R.: A high-resolution mass spectrometer to measure atmospheric ion composition, Atmos. Meas. Tech., 3, 10391053, doi:10.5194/amt-3-1039-2010, 2010.

Jurányi, Z., Gysel, M., Duplissy, J., Weingartner, E., Tritscher, T., Dommen, J., Henning, S., Ziese, M., Kiselev, A., Stratmann, F., George, I., and Baltensperger, U.: Influence of gas-to-particle partitioning on the hygroscopic and droplet activation behaviour of $\alpha$-pinene secondary organic aerosol. Phys. Chem. Chem. Phys., 11, 8091-8097, doi:10.1039/b904162a, 2009.

Kanakidou, M., Seinfeld, J. H., Pandis, S. N., Barnes, I., Dentener, F. J., Facchini, M. C., Van Dingenen, R., Ervens, B., Nenes, A., Nielsen, C. J., Swietlicki, E., Putaud, J. P., Balkanski, Y., Fuzzi,
S., Horth, J., Moortgat, G. K., Winterhalter, R., Myhre, C. E. L., Tsigaridis, K., Vignati, E., Stephanou, E. G., and Wilson, J.: Organic aerosol and global climate modelling: a review, Atmos. Chem. Phys., 5, 1053-1123, doi:10.5194/acp-5-1053-2005, 2005.

Kim, T. O., Ishida, T., Adachi, M., Okuyama, K., and Seinfeld, J. H.: Nano-meter sized particle formation from $\mathrm{NH}_{3} / \mathrm{SO}_{2} / \mathrm{H}_{2} \mathrm{O} /$ air mixtures by ionizing irradiation, Aerosol Sci. Technol., 29, 111125, 1998.

King, S. M., Rosenoern, T., Shilling, J. E., Chen, Q., and Martin, S. T.: Increased cloud activation potential of secondary organic aerosol for atmospheric mass loadings, Atmos. Chem. Phys., 9, 2959-2971, doi:10.5194/acp-9-2959-2009, 2009.

Kirkby, J., Curtius, J., Almeida, J., Dunne, E., Duplissy, J., Ehrhart, S., Franchin, A., Gagne, S., Ickes, L., Kurten, A., Kupc, A., Metzger, A., Riccobono, F., Rondo, L., Schobesberger, S., Tsagkogeorgas, G., Wimmer, D., Amorim, A., Bianchi, F., Breitenlechner, M., David, A., Dommen, J., Downard, A., Ehn, M., Flagan, R. C., Haider, S., Hansel, A., Hauser, D., Jud, W., Junninen, H., Kreissl, F., Kvashin, A., Laaksonen, A., Lehtipalo, K., Lima, J., Lovejoy, E. R., Makhmutov, V., Mathot, S., Mikkila, J., Minginette, P., Mogo, S., Nieminen, T., Onnela, A., Pereira, P., Petaja, T., Schnitzhofer, R., Seinfeld, J. H., Sipila, M., Stozhkov, Y., Stratmann, F., Tome, A., Vanhanen, J., Viisanen, Y., Vrtala, A., Wagner, P. E., Walther, H., Weingartner, E., Wex, H., Winkler, P. M., Carslaw, K. S., Worsnop, D. R., Baltensperger, U., and Kulmala, M.: Role of sulphuric acid, ammonia and galactic cosmic rays in atmospheric aerosol nucleation, Nature, 476, 429-433, 2011.

Knutson E. O. and Whitby K. T.: Accurate measurement of aerosol electric mobility moments, J. Aerosol Sci., 6, 453-460, 1975.

Kulmala, M., Vehkamäki, H., Petaja, T., Dal Maso, M., Lauri, A., Kerminen, V. M., Birmili, W., and McMurry, P.: Formation and growth rates of ultra fine atmospheric particles: A review of observations, J. Aerosol Sci., 35, 143-176, 2004.

Kupc A., Amorim, A., Curtius, J., Danielczok, A., Duplissy, J., Ehrhart, S., Walther, H., Ickes, L., Kirkby, J., Kürten, A., Lima, J. M., Mathot, S., Minginette, P., Onnela, A., Rondo, L., and Wagner, P. E.: A fibre-optic UV system for $\mathrm{H}_{2} \mathrm{SO}_{4}$ production in aerosol chambers causing minimal thermal effects, J. Aerosol Sci., 42, 532-543, 2011.

Kurtén, T., Petäjä, T., Smith, J., Ortega, I. K., Sipilä, M., Junninen, H., Ehn, M., Vehkamäki, H., Mauldin, L., Worsnop, D. R., and Kulmala, M.: The effect of $\mathrm{H}_{2} \mathrm{SO}_{4}-$ amine clustering on chemical ionization mass spectrometry (CIMS) measurements of gas-phase sulfuric acid, Atmos. Chem. Phys., 11, 3007-3019, doi:10.5194/acp-11-3007-2011, 2011.

Laaksonen, A., Kulmala, M., O’Dowd, C. D., Joutsensaari, J., Vaattovaara, P., Mikkonen, S., Lehtinen, K. E. J., Sogacheva, L., Dal Maso, M., Aalto, P., Petäjä, T., Sogachev, A., Yoon, Y. J., Lihavainen, H., Nilsson, D., Facchini, M. C., Cavalli, F., Fuzzi, S., Hoffmann, T., Arnold, F., Hanke, M., Sellegri, K., Umann, B., Junkermann, W., Coe, H., Allan, J. D., Alfarra, M. R., Worsnop, D. R., Riekkola, M. -L., Hyötyläinen, T., and Viisanen, Y.: The role of VOC oxidation products in continental new particle formation, Atmos. Chem. Phys., 8, 2657-2665, doi:10.5194/acp-82657-2008, 2008.

Lance, S., Medina, J., Smith, J. N., and Nenes, A.: Mapping the operation of the DMT continuous flow CCN counter, Aerosol Sci. Technol., 40, 242-254, 2006. 
Massoli, P., Lambe, A. T., Ahern, A. T., Williams, L. R., Ehn, M., Mikkilä, J., Canagaratna, M. R., Brune, W. H., Onasch, T. B., Jayne, J. T., Petäjä, T., Kulmala, M., Laaksonen, A., Kolb, C. E., Davidovits, P., and Worsnop, D. R.: Relationship between aerosol oxidation level and hygroscopic properties of laboratory generated secondary organic aerosol (SOA) particles, Geophys. Res. Lett., 24, L24801, doi:10.1029/2010GL045258, 2010.

Merikanto, J., Spracklen, D. V., Mann, G. W., Pickering, S. J., and Carslaw, K. S.: Impact of nucleation on global CCN, Atmos. Chem. Phys., 9, 8601-8616, doi:10.5194/acp-9-8601-2009, 2009.

Meyer, N. K., Duplissy, J., Gysel, M., Metzger, A., Dommen, J., Weingartner, E., Alfarra, M. R., Prevot, A. S. H., Fletcher, C., Good, N., McFiggans, G., Jonsson, A.. M., Hallquist, M., Baltensperger, U., and Ristovski, Z. D.: Analysis of the hygroscopic and volatile properties of ammonium sulphate seeded and unseeded SOA particles, Atmos. Chem. Phys., 9, 721-732, doi:10.5194/acp-9-721-2009, 2009.

Nieminen, T., Lehtinen, K. E. J., and Kulmala, M.: Sub-10 nm particle growth by vapor condensation - effects of vapor molecule size and particle thermal speed, Atmos. Chem. Phys., 10, 97739779, doi:10.5194/acp-10-9773-2011, 2010.

Petäjä, T., Kerminen, V.-M., Hämeri, K., Vaattovaara, P., Joutsensaari, J., Junkermann, W., Laaksonen, A., and Kulmala, M.: Effects of $\mathrm{SO}_{2}$ oxidation on ambient aerosol growth in water and ethanol vapours, Atmos. Chem. Phys., 5, 767-779, doi:10.5194/acp-5-767-2005, 2005.

Petters, M. D. and Kreidenweis, S. M.: A single parameter representation of hygroscopicity growth and cloud condensation nucleus activity, Atmos. Chem. Phys., 7, 1961-1971, doi:10.5194/acp-71961-2007, 2007.

Pierce, J. R., Riipinen, I., Kulmala, M., Ehn, M., Petäjä, T., Junninen, H., Worsnop, D. R., and Donahue, N. M.: Quantification of the volatility of secondary organic compounds in ultrafine particles during nucleation events, Atmos. Chem. Phys., 11, 90199036, doi:10.5194/acp-11-9019-2011, 2011.

Praplan, A. P., Bianchi, F., Dommen, J., and Baltensperger, U.: Dimethylamine and ammonia measurements with ion chromatography during the CLOUD4 campaign, Atmos. Meas. Tech., 5, 2161-2167, doi:10.5194/amt-5-2161-2012, 2012.

Pruppacher, H. R. and Klett, J. D.: Microphysics of Clouds and Precipitation, Atmospheric and oceanographic sciences library, Kluwer Academic Publishers, Dordrecht, the Netherlands, 2nd edn., 1997.

Raatikainen, T., Vaattovaara, P., Tiitta, P., Miettinen, P., Rautiainen, J., Ehn, M., Kulmala, M., Laaksonen, A., and Worsnop, D. R.: Physicochemical properties and origin of organic groups detected in boreal forest using an aerosol mass spectrometer, Atmos. Chem. Phys., 10, 2063-2077, doi:10.5194/acp-10-20632010, 2010.

Reischl, G. P.: Measurement of ambient aerosols by the different mobility analyzer method: concepts and realization criteria for the size range between 2 and $500 \mathrm{~nm}$, Aerosol Sci. Technol., 14, 5-24, 1991.

Riccobono, F., L. Rondo, M. Sipilä, P. Barmet, J. Curtius, J. Dommen, M. Ehn, S. Ehrhart, M. Kulmala, A. Kurten, J. Mikkila, T. Petaja, E. Weingartner, and U. Baltensperger: Contribution of sulfuric acid and oxidized organic compounds to particle formation and growth, Atmos. Chem. Phys., 12, 9427-9439, 2012, http://www.atmos-chem-phys.net/12/9427/2012/.

Riipinen, I., Yli-Juuti, T., Pierce, J. R., Petaja, T., Worsnop, D. R., Kulmala, M., and Donahue, N.: Role of organics in atmospheric nanoparticle growth - recent breakthroughs and major unknowns, Nature Geosci., 5, 453-458, 2012.

Ristovski, Z. D., Suni, T., Kulmala, M., Boy, M., Meyer, N. K., Duplissy, J., Turnipseed, A., Morawska, L., and Baltensperger, U.: The role of sulphates and organic vapours in growth of newly formed particles in a eucalypt forest, Atmos. Chem. Phys., 10, 2919-2926, doi:10.5194/acp-10-2919-2010, 2010.

Roberts, G. and Nenes, A. A.: Continuous-flow streamwise thermalgradient $\mathrm{CCN}$ chamber for atmospheric measurements, Aerosol Sci. Technol., 39, 206-221, 2005.

Seinfeld, J. H. and Pandis, S. N.: Atmospheric Chemistry and Physics, from Air Pollution to Climate Change, John Wiley, New York, 519-523, 1998.

Smith M. L., Kuwata M., and Martin T.: Secondary organic material produced by the dark ozonolysis of $\alpha$-pinene minimally affects the deliquescence and efflorescence of ammonium sulfate, Aerosol Sci. Tech., 45, 244-261, 2011.

Smith, M. L., Bertram, A. K., and Martin, S. T.: Deliquescence, efflorescence, and phase miscibility of mixed particles of ammonium sulfate and isoprene-derived secondary organic material, Atmos. Chem. Phys., 12, 9613-9628, doi:10.5194/acp-12-96132012, 2012.

Sullivan, R. C., Petters, M. D., DeMott, P. J., Kreidenweis, S. M., Wex, H., Niedermeier, D., Hartmann, S., Clauss, T., Stratmann, F., Reitz, P., Schneider, J., and Sierau, B.: Irreversible loss of ice nucleation active sites in mineral dust particles caused by sulphuric acid condensation, Atmos. Chem. Phys., 10, 1147111487, doi:10.5194/acp-10-11471-2010, 2010.

Tang, I. N. and Munkelwitz, H. R.: Water activities, densities, and refractive-indexes of aqueous sulfates and sodium-nitrate droplets of atmospheric importance, J. Geophys. Res. Atmos., 99, 18801-18808, 1994.

Topping, D. O., McFiggans, G. B., and Coe, H.: A curved multicomponent aerosol hygroscopicity model framework: Part 1 - Inorganic compounds, Atmos. Chem. Phys., 5, 1205-1222, doi:10.5194/acp-5-1205-2005, 2005.

Vaattovaara, P., Räsänen, M., Kühn, T., Joutsensaari, J., and Laaksonen, A.: A method for detecting the presence of organic fraction in nucleation mode sized particles, Atmos. Chem. Phys., 5, 3277-3287, doi:10.5194/acp-5-3277-2005, 2005.

Vaattovaara, P., Petäjä, T., Joutsensaari, J., Miettinen, P., Zaprudin, B., Kortelainen, A., Heijari, J., Yli-Pirilä, P., Aalto, P., Worsnop, D. R., and Laaksonen, A.: The evolution of nucleation- and Aitken-mode particle compositions in a boreal forest environment during clean and pollution-affected new-particle formation events, Boreal Environ. Res., 14, 662-682, 2009.

VanReken, T. M., Ng, N. L., Flagan, R. C., and Seinfeld, J. H.: Cloud condensation nucleus activation properties of biogenic secondary organic aerosol, J. Geophys. Res., 110, D07206, doi:10.1029/2004JD005465, 2005.

Vehkamäki, H., Kulmala, M., Napari, I., Lehtinen, K. E. J., Timmreck, C., Noppel, M., and Laaksonen, A.: An improved parameterization for sulfuric acid-water nucleation rates for tropospheric and stratospheric conditions, J. Geophys. Res., 107, 4622, doi:10.1029/2002JD002184, 2002. 
Voigtländer, J., Duplissy, J., Rondo, L., Kürten, A., and Stratmann, F.: Numerical simulations of mixing conditions and aerosol dynamics in the CERN CLOUD chamber, Atmos. Chem. Phys., 12, 2205-2214, doi:10.5194/acp-12-2205-2012, 2012.

Wex, H., Petters, M. D., Carrico, C. M., Hallbauer, E., Massling, A., McMeeking, G. R., Poulain, L., Wu, Z., Kreidenweis, S. M., and Stratmann, F.: Towards closing the gap between hygroscopic growth and activation for secondary organic aerosol: Part $1-$ Evidence from measurements, Atmos. Chem. Phys., 9, 3987-3997, doi:10.5194/acp-9-3987-2009, 2009.
Wexler, A. S. and Clegg, S. L.: Atmospheric aerosol models for systems including the ions $\mathrm{H}^{+}, \mathrm{NH}_{4}^{+}, \mathrm{Na}^{+}, \mathrm{SO}_{4}^{2-}$, $\mathrm{NO}_{3}^{-}, \mathrm{Cl}^{-}, \mathrm{Br}^{-}$and $\mathrm{H}_{2} \mathrm{O}$, J. Geophys. Res., 107, 4207, doi:10.1029/2001JD000451, 2002. 